\title{
INVESTIGATION OF HEAT TRANSFER COEFFICIENT AUGMENTATION IN DIVERGENT RECTANGULAR DUCT FOR TWO PHASES FLOW (AIR-WATER)
}

\author{
Hadi O. Basher ${ }^{1}$ \\ dr.albasher@yahoo.com \\ Riyadh S. Al-Turaihi ${ }^{2}$ \\ drriyadhalturaihi@yahoo.com \\ Ahmed A. Shubbar ${ }^{3}$ \\ alish227@uowasit.edu.iq \\ ${ }^{1,3}$ Mechanical Engineering Department, College of Engineering, Waist University, Waist, Iraq. \\ ${ }^{2}$ Mechanical Engineering Department, College of Engineering, Babylon University, Babylon, Iraq.
}

\begin{abstract}
In this project, the flow distribution for air and water, and the enhancement of the heat transfer coefficient are experimentally studied. Experimental studies have been performed to test the influence of discharge, pitch, the height of ribs at a constant heat flux on the temperature and pressure distributions. Along the channel of the test and the heat transfer coefficient, the water volume flow rate was about $(5-12 \mathrm{~L} / \mathrm{min})$, the air volume flow rate was about (5.83-16.66 L/min), and heat were (80, 100,120, watt). An experimental rig was constructed within the test whole system. On the other hands, the channel has a divergent section with an angle $=150$ with vertical axis. The study included changing in the ribs height by using three values $(12,15,18 \mathrm{~mm})$ and changing the ribs pitch into three values $(5,8,10$ $\mathrm{mm}$ ). The results indicated an increasing in the local heat transfer coefficient as a result of increasing the discharge. While there was an inverse influence for the temperature distribution along the test channel which drops when the discharge rise. The results also confirm that the increasing in the pitch distance leads to reduce the heat transfer coefficient. Increasing the ribs height increases the coefficient of heat transfer. However, the experiment heat transfer coefficient improves about $(15.6 \%)$ when the water volume flow rate increased from (5 to 12 $\mathrm{L} / \mathrm{min}$ ), and about $(18.7 \%)$ when the air volume flow rate increased from (5.83 to 16.66 $\mathrm{L} / \mathrm{min}$ ). The best heat transfer coefficient was about (35.6\%) which can be achieved when the pitch decreased from (10 to $5 \mathrm{~mm}$ ). The increasing of the height from (12 to 18$) \mathrm{mm}$ improves the heat transfer coefficient about $(11.2 \%)$. The best rib dimension was $18 \mathrm{~mm}$ height, and $5 \mathrm{~mm}$ pitch, which give a maximum heat transfer coefficient $\left(1212.02 \mathrm{~W} / \mathrm{m} 2 .{ }^{\circ} \mathrm{C}\right)$.
\end{abstract}

Keywords: Divergent Coefficient, Rectangular Duct, Two Phases Flow (Air-Water).

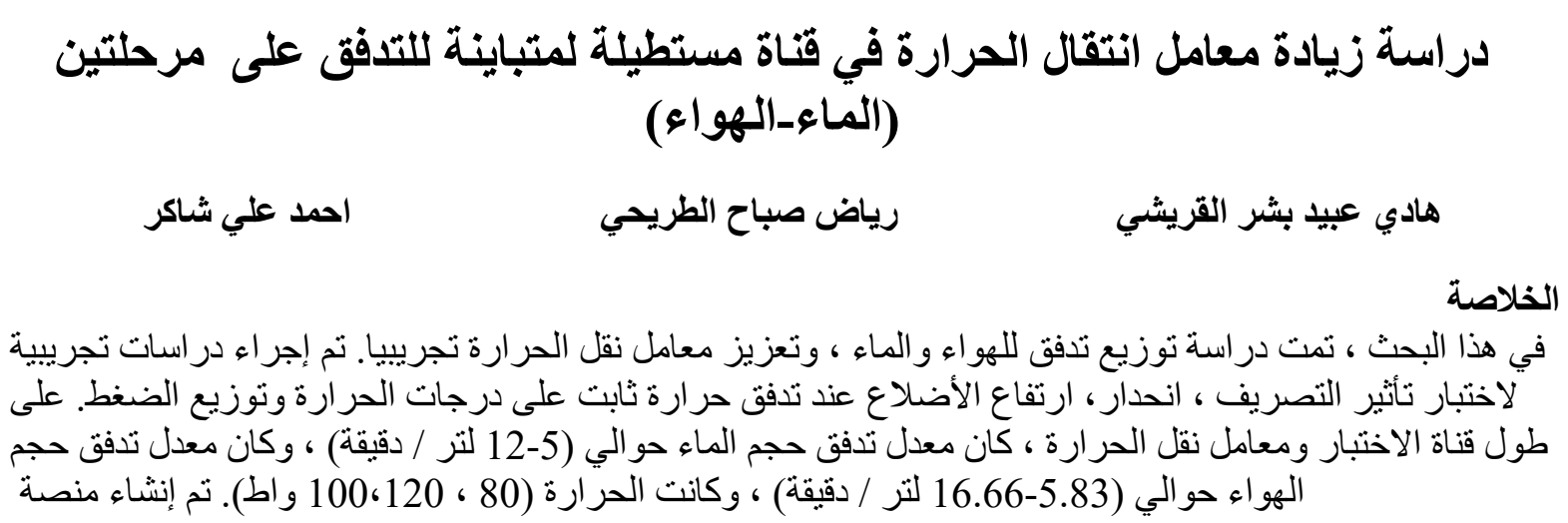


تجريبية داخل نظام الاختبار بالكامل. من ناحية أخرى ، تحتوي القناة على قسم منباعد بزاوية 15 درجة مع الإع المحور

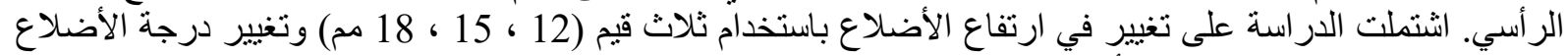

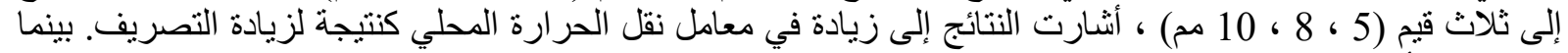

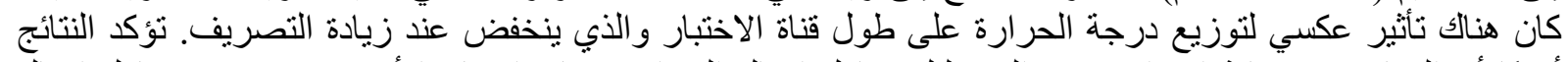

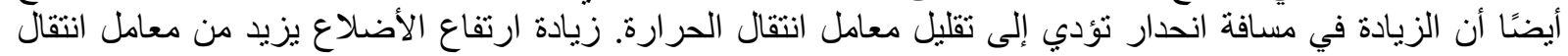

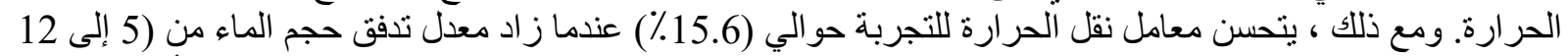

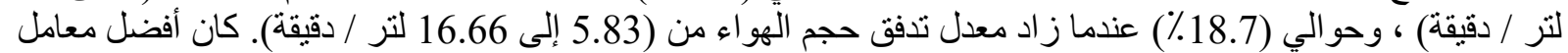

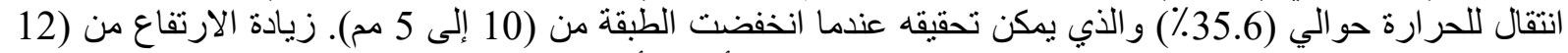

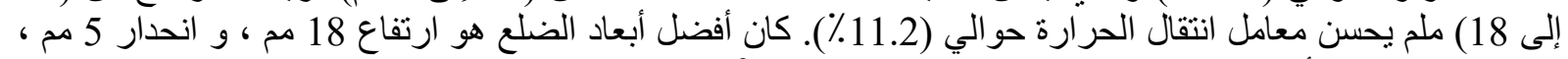

\section{INTRODUCTION}

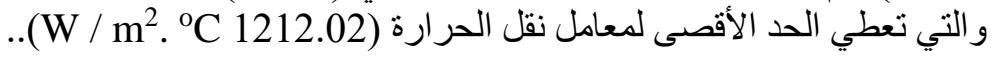

The excessive cost of power and material has led to an extended effort toward generating efficient heat transfer equipment [Al-Naely, et al. (2018); Al-Zubaidy, et al. (2019); Salih, et al. (2019); Yaseen, et al. (2019); Tian, et al. (2020)]. The requiremefnt of improving the heat transfer in thermal systems is very important for saving energy. Therefore, there are several researches with various techniques have been presented. The re-configuration of geometry is one of the techniques to increase the efficiency of heat exchangers and save costs and energy [Abdulrazzaq Guptaa, et al. (2013); Togun, (2016); Al-Jibory (2018); Golam (2018); and Guptaa, et al. (2018]. The usage of the rough elements which include grooves, wires or welded ribs on the surface, or turbulence promoters, is a popular approach to enhance the heat transfer [Promvonge, et al. (2012); Piriyarungrod, et al. (2015); Bhuiya, et al. (2016); and Zhang, et al. (2016)]. The wide variety of studies on heat transfer and flow characteristics had been finished to investigate the impact of rib designed parameters. These parameters included rib height, the angle of attack, relative roughness pitch, rib arrangement and rib cross-section. However, the synthetically roughness causes in higher losses due to the major friction force which leads to excessive power requirement for the fluid to drift through the duct. It's suited that the turbulence has to be created best in a place very close to the heat- transferring surface in order to interrupt the viscous sub-layer for augmenting the heat transfer. Ansari and Arzandi (2012), experimentally investigated the air water two phase flow using rectangular ducts that are smooth and ribbed to demonstrate the effect of ribs' height on the boundaries, they also presented a flow map diagram. Three ribs of various heights $(1,2$, and $4 \mathrm{~mm})$ were utilized; the rib width $(10 \mathrm{~mm})$ and pitch $(50 \mathrm{~mm})$ were held constant. The ribs were positioned in the duct at three various locations to establish three various conditions. It was found that, increasing of the rib height initiated hydro-dynamical instability at lower fluid velocities [Turaihi, et al. (2018) and Van Eckeveld, et al. (2018)]. Karthikeyan et al. (2015), experimentally studied the influence of the rib's height on the heat transfer and fluid characteristics of air flow in a convergent/divergent rectangular channel with an inclination angle of $1^{\circ}$ in y-direction. For a various height square ribbed ducts 3, 6, 9, and $12 \mathrm{~mm}$ with various hydraulic mean diameter 34.8, 69.7, 104.6, $138.7 \mathrm{~mm}$ at constant rib pitch distance is $60 \mathrm{~mm}$. Constant heat flux applied by utilizing two ceramic heating strip of $10 \mathrm{~mm}$ thickness which has been attached on the bottom and top surfaces for the test sections where the Re based on the hydraulic mean diameter is $86 \mathrm{~mm}$ of the channel varied from 20000 to 50000 . They demonstrated that the increase in rib height the strength and size of recirculation zone increases. Enhanced heat transfer behavior observed for a divergent duct for four various rib sizes, while the convergent duct has got a reduction in heat transfer performance [(Sivakumar, et al. (2018); Kashif, et al. (2018); and Sorour, et al. (2019)]. Kong and Kim (2017); Kong et al. (2018) and Kong et al. (2016), performed experimental studies to characterize the horizontal two _ phase (air-water) flow in a round pipe with an inner diameter of $(3.81) \mathrm{cm}$. 
Visualization of the flow was done by using a high-speed video camera in an extensive range of two-phase flow conditions to verify the previous flow regime maps. They were classified into bubbly, plug, slug, stratified, stratified-wavy, and annular flows. As a result, new transition boundaries were developed, the results displayed that the transition from bubbly flow to plug/slug flow depends on gas superficial velocity (jg). Hanafizadeh et al. (2017) experimentally investigated flow pattern of air-water-oil three-phases in an inclined upward and downward pipe by using a high-speed digital camera with $20 \mathrm{~mm}$ diameter and $6 \mathrm{~m}$ length. The range of the inclination angles of pipe are $-45^{\circ}$ to $+45^{\circ}$ for three various oil cuts of $25 \%, 50 \%$ and $75 \%$ for each inclination angle. They investigated the influence of inclination angle and a liquid volume fraction of the flow patterns of air-water-oil three-phase flow. In addition, they get seven typical three-phase flow patterns bubbly-oil in water, stratified-oil in water, plug-stratified, plug-oil in water, slug oil in water, wavy stratified-oil in water and annular-oil in water. Results demonstrated that by increasing the oil cut for various inclination angles, a plug region becomes smaller and bubbly region extends. The major objective of this work is to study an experimental the impact of water and air superficial velocities and the ribs' dimensions (pitch and height) on heat transfer coefficient and temperature distribution in a rectangular channel which has compound turbulators with divergent section. The working fluid is water and air with various discharge.

\section{EXPERIMENTAL APPARATUS AND PROCEDURE The experimental test rig and measurements}

The rig was built up in the fluid laboratories of Mechanical Engineering. A schematic of the test section, the outlet of two-phase flow and the experimental test rig are demonstrated in figure(1) respectively. The experiments were carried out at ambient laboratory conditions of approximately $25^{\circ} \mathrm{C}$ temperature and atmospheric pressure.

\section{The Assembling of the Test sections}

\section{The Major channel}

The major channel is a transparent Perspex pipe, which can be seen in figure. (2a), with a rectangular cross section area of (20x60) $\mathrm{mm}$ and $500 \mathrm{~mm}$ height, then the region diverted at angle $=15^{\circ}$ until the width of the duct becomes $80 \mathrm{~mm}$, and the height continues $500 \mathrm{~mm}$ after divergent the section. Also, the rib is installed in the middle of the divergent section which has a water pipe with $25.4 \mathrm{~mm}$ diameter, and an air pipe with $10 \mathrm{~mm}$ diameter. The water pipe is connected into a duct by a funnel, the air is injected by a tube passing through the water pipe. Mixing of the air phase and the liquid phase firstly within the steel funnel at the inlet of the duct. The liquid and gas phases are mixed inside the channel prior to the divergent section. When the two-phase mixture flows from the test section, liquid and gas phases are separated into the liquid storage tank. The five sensors are fixed to measure the flow temperature of two-phase flow within the duct. One sensor is set above the ribs, two others before the ribs and two others after the ribs, the distance between sensors is $100 \mathrm{~mm}$, as demonstrated in figure(2a) photograph of major channel.

\section{The Ribs}

Ribs are design and manufactured from aluminum material with thermal conductivity (202.4 $\mathrm{W} / \mathrm{m}$. K). And the ribs manufacturing process have been performed in one of the engineering laboratories by specialized engineers who utilized a digital milling machine (CNC). And then, the ribs are mounted and fixed by screw and nut on the wall back side of the rectangular channel at a divergent region from the test section. Figure(2b) demonstrates the ribs that have been utilized in the present work, and figure $(2 \mathrm{c})$ demonstrates the rips inside the major channel. 


\section{The Heating System}

The heating system consists of two major heaters with (110 and 15) mm length and the total voltage of the major heater is $220 \mathrm{~V}$. A controller is utilized to maintain a constant heat flux on the outer surface of the ribs. Two heaters are mounted and fixed by a hole inside the rib from the back-rib surface. Heaters are utilized to convert electrical energy coming from power analyzer device into a heat, as demonstrated in figure(3).

\section{Experimental procedure}

The procedure for these experiments is listed as follows: The first rib will be attached to the channel. Then, turning on the water centrifugal pump on $(5 \mathrm{~L} / \mathrm{min})$ as an initial value. With supplying the heaters with an electrical power at the first value of $(80 \mathrm{~W})$. Then, waiting for (5-10 $\mathrm{min})$ until the rib up to constant temperature to turn on the air compressor on (5.83 $\mathrm{L} / \mathrm{min}$ ) as an initial value. To start recording the temperature by sensors which are placed at five various points along the section of test and a sensor in the rib. The previous procedure repeated for the four various values of air flow rate and water flow rate, the three various values of heat flux. Also all the procedure repeated for the other type of ribs. The experimental work cases are demonstrated in the Table (1). Every experiment repeated at least two times to make sure of the results. Calculate heat transfer coefficient from equation:

$$
h=\frac{\mathrm{q}}{\mathrm{A}(\mathrm{Tr}-\mathrm{Tf})}
$$

As well as the general definition of the heat transfer coefficient is:

$$
h=\frac{q}{\Delta T}
$$

Therefore the heat coefficient is $(1212.02,1221.11,1246.82$, and 1226.65$) \mathrm{W} / \mathrm{m}^{2} .{ }^{\circ} \mathrm{C}$.

\section{RESULTS AND DISCUSSION}

\section{Air Volume Flow Rate Relationship with Heat Transfer Coefficient}

Table. 2 to Table. 4 demonstrate the air volume flow rate relationship with heat transfer coefficient for a various water flow rate value. In Table. 2 this experimental result for a case which has $80-\mathrm{W}$, pitch distance $=5 \mathrm{~mm}$, and height $=18 \mathrm{~mm}$. It can be observed that the heat transfer coefficient was increased with increasing water flow rate due to the air bubbles which lead to increase the turbulence and the heat transfer coefficient. This influence can be noticed when the air flow rate has been increased from $(5.83 \mathrm{~L} / \mathrm{min}$ to 16.8$) \mathrm{L} / \mathrm{min}$, where the heat transfer coefficient enhanced ratio about $(18.7 \%, 20.8 \%)$ at a water flow rate $(5,7) \mathrm{L} / \mathrm{min}$ ) respectively. Table. 2 to Table. 4 demonstrate the similar response by using of the same rib dimensions, but the heat value is (100-watt and $120-\mathrm{W})$, respectively. However, the increasing in the heat value lead to increase the heat transfer coefficient due to increase the temperature variance between ribs surface and fluid.

\section{The influence of Pitch on Heat Transfer Coefficient}

Table. 2 to Table. 4 demonstrate the influence of pitch on a heat transfer coefficient at air volume flow rate $=5.83 \mathrm{~L} / \mathrm{min}$. Also, in Table 2 the heat value $=80$-watt and height $=18 \mathrm{~mm}$. So, it can be observed that heat transfer coefficient decreased with increasing the pitch distance for all water flow rate values because of increasing the pitch will decrease a rib surface area and increase temperature variance. Therefore, at water flow rate $=5 \mathrm{~L} / \mathrm{min}$, the heat transfer coefficient will be decreased about $(35.6 \%)$ when the pitch distance increased about $5 \mathrm{~mm}$. So that from these experimental results can be confirmed that the heat transfer coefficient is adversely affected by increasing pitch, but it will increase with increasing the amount of heat. 


\section{Height of Rib Influence on Heat Transfer Coefficient}

Table. 2 to Table. 4 perceive the heat transfer coefficient variation with height of rib. At various value of water volume flow rate and at pitch distance $5 \mathrm{~mm}$. It can be seen that increasing the height of the rib will increase the heat transfer coefficient between the rib and flowing fluids. That due to the increasing of rib's surface area. For all value of water flow rate heat transfer coefficient increase with increase height, but with height value of with height of rib at three values of heat $(80,100$, and 120) watt respectively. When flow rate is $5 \mathrm{~L} / \mathrm{min}$ for water and $5.83 \mathrm{~L} / \mathrm{min}$ for air. It can be noticed that at $12 \mathrm{~mm}$ height of rib is higher value of heat transfer Coefficient then when height increase. The temperature variances decrease and Surface area increase. So that the influence of the increasing the surface area is more effective than the decreasing in the temperature various before $15 \mathrm{~mm}$ height, so that it can be noted that heat transfer coefficient drops, then after $15 \mathrm{~mm}$ the influence of decrease temperature variance is more than surface area increase so that the heat transfer coefficient behavior is increase. Table. 2 to Table. 4 perceives the heat transfer coefficient relationship with pitch distance for three values of heat $(80,100$, and 120) Watt respectively at flow condition is 5 $\mathrm{L} / \mathrm{min}$ for water and 5-83 L/min for air. Heat transfer coefficient has a liner relationship with pitch distance, for all three decreases with pitch increasing and that due to pitch increment reduces surface area of rib, but increases temperature variance. So that the heat transfer

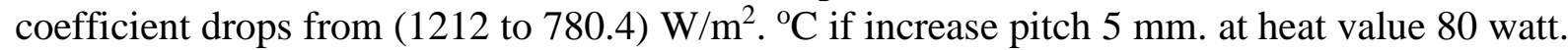
So that this result explains the important of surface area on heat transfer coefficient. Because in this study the surface area is variables with pitch and height.

\section{Temperature Profile}

Table. 2 to Table. 4 show temperature profile for a range of water flow rate $(5,7,9$, and 12$)$ $\mathrm{L} / \mathrm{min}$ at heat value of 80 -watt and rib dimensions is $18 \mathrm{~mm}$ and $5 \mathrm{~mm}$, height and pitch respectively. At Table. 2 to Table. 4 when water flow rate is $5 \mathrm{~L} / \mathrm{min}$ and Air flow rate is 5.83 $1 / \mathrm{min}$, the temperature of mixing fluid at the rib section is reach to $\left(29 .{ }^{\circ} \mathrm{C}\right)$ when air discharge increases to $(8.33 \mathrm{~L} / \mathrm{min})$ the temperature slightly increases to $\left(29.3{ }^{\circ} \mathrm{C}\right)$ in rib section because of increase turbulence due to increase air so that heat transfer coefficient increase. Also, in Table. 2 to Table. 4 the water flow rate increase, with the temperature decrease and heat transfer coefficient increase due to decrease in the time residence of mixing. (Water and air) and increase the amount of water inside. The channel "and adding of ribs increase the surface area of heat transfer and interrupt the development of a boundary layer of flow and create turbulence flow "inside the channel temperature behavior, it can be noted that, Table. 2 to Table. 4 devote temperature relationship with vertical distance. At the rib dimensions: height $=18 \mathrm{~mm}$ and pitch $=5 \mathrm{~mm}$ which at range of air discharge $(5.83,8.33$, 10.83 and 16.66) $\mathrm{L} / \mathrm{min}$ and heat water is 100 , when the water increased the temperature will decrease. Due to decrease in the time residence of mixing water and air and increase the amount of water inside the channel, at heat value 100 watt and water flow rate $(5 \mathrm{~L} / \mathrm{min})$ the temperature of fluid near the rib surface is $\left(30,30.2,30.4\right.$, and $\left.30.7^{\circ} \mathrm{C}\right)$ at the air discharge $(5.83,8.33,10.83$, and 16.83$) \mathrm{L} / \mathrm{min}$ respectively.

\section{CONCLUSIONS}

This work presented an experimental study for convective heat transfer coefficient and temperature distribution in vertical rectangular divergent channel with two triangular ribs for various dimensions with two-phase flow (water -air) and uniform heat (80, 100, 120 watt). The following conclusions are drawn from this work:

1. Experimental local heat transfer coefficient was improved about $(15.6 \%)$ due to increase the water discharge from ( 5 to $12 \mathrm{~L} / \mathrm{min}$ ) for a constant heat ( 80 watt), and improved about $(18.7,18.1) \%$ respectively as a result of increasing the air discharge from $(5.83$ to $16.66 \mathrm{~L} / \mathrm{min})$. 
2. Local heat transfer coefficient decreased about (35.6\%) with increasing the pitch distance from ( 5 to $10 \mathrm{~mm}$ ), when the ribs' height $=18 \mathrm{~mm}$, constant heat $=80$-watt, water flow $=5 \mathrm{~L} / \mathrm{min}$ and the water flow rate of air $=5.83 \mathrm{~L} / \mathrm{min}$. And it decreased about $(31.9 \%)$ with increasing the pitch distance from $(5$ to $10 \mathrm{~mm})$ in heat value $=100$ watt, and decreased about $(27.8 \%)$ when the heat value $=120$ watt.

3. Increasing the ribs' height from 12 to $18 \mathrm{~mm}$, was caused an increasing in the local heat transfer coefficient about $(11.1 \%)$ at flow condition $(5,5.83 \mathrm{~L} / \mathrm{min})$ for water and air respectively. At heat value $=80$ watt and heat value $=100$ watt, there will be an enhancement in the heat transfer coefficient which about $(12.5 \%)$.

4. Increasing the water discharge from ( 5 to $12 \mathrm{~L} / \mathrm{min}$ ) and air discharge from (5.83 to $16.66 \mathrm{~L} / \mathrm{min}$ ) when the height $=18$, pitch $=5 \mathrm{~mm}$ will lead to improve the heat transfer coefficient about (37.8\%) for a channel with heat 80 watt, the increasing ratio about $(35.1 \%)$ for a channel with heat 100 watt and about $(35.7 \%)$ for a channel with heat 120 watt.

5. Temperature distribution has an inverse proportional with water and air superficial velocities along the channel for (water-air) two - phase flow, so increasing these variables lead to decrease the temperature variance along the channel.

\section{Acknowledgment}

This work was supported and funded by University of Waist, College of Engineering, Department of Mechanical Engineering.

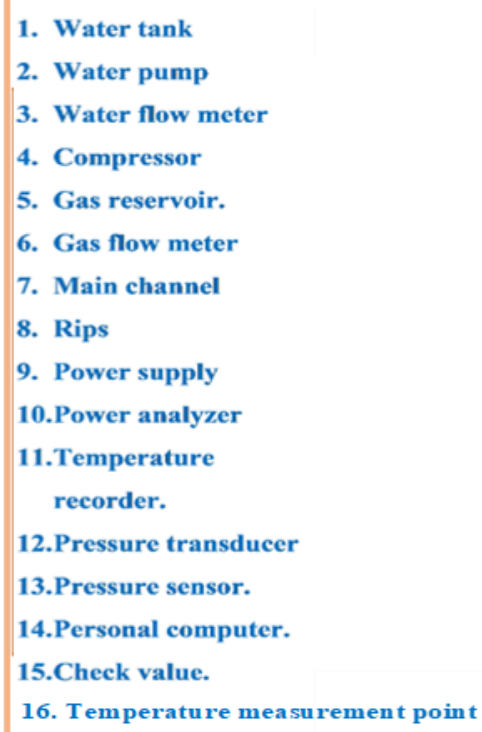

Fig. (1): schematic diagram for the experimental test rig.

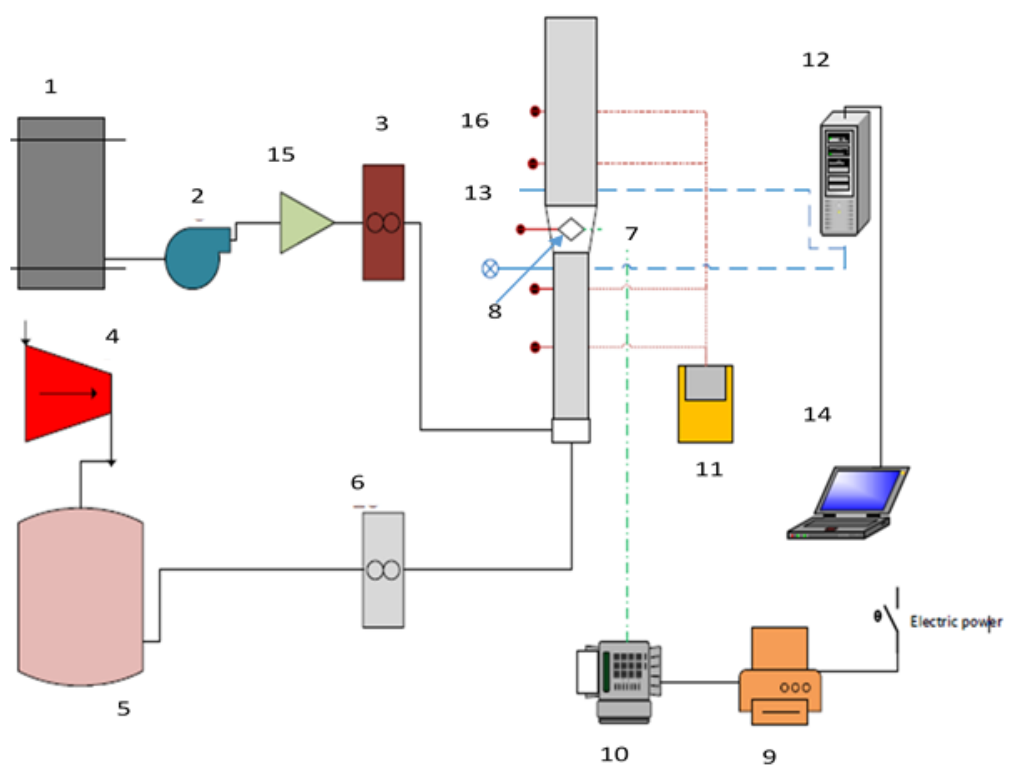



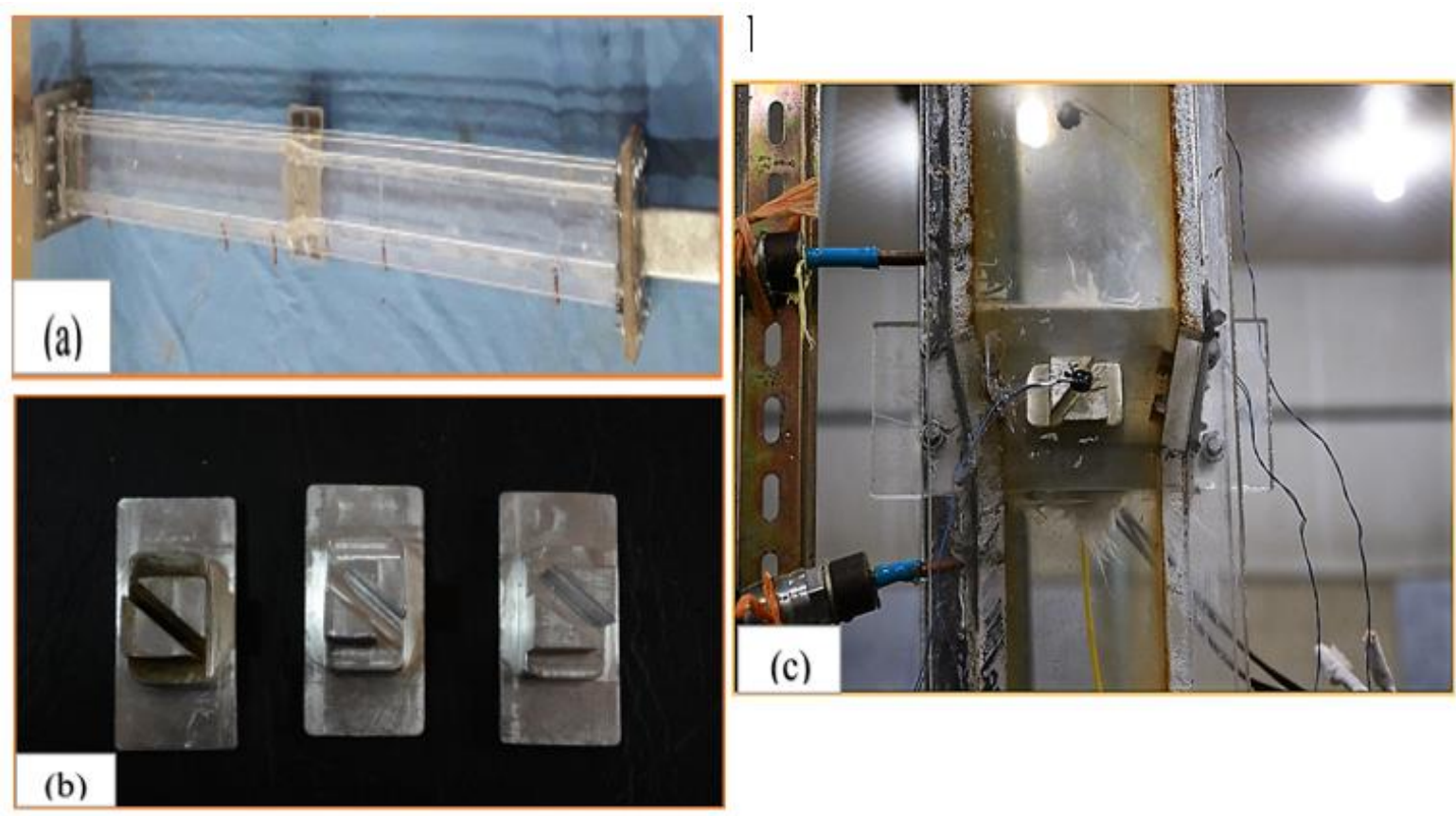

Fig. (2): Pictures of (a) the major channel (b) view of all rib cases (c) rib inside the divergence section.
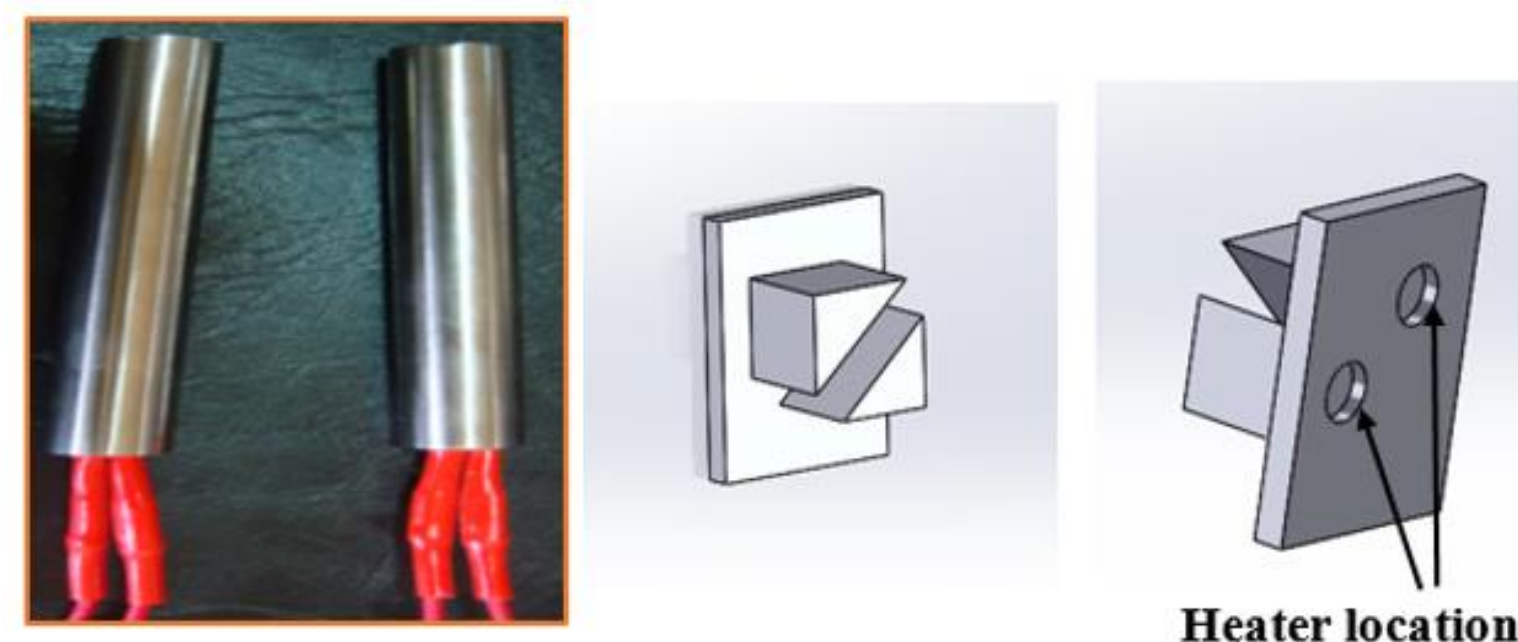

Heater location

Fig. (3): heating system.

Table 1: Values of the experimental work conditions.

\begin{tabular}{|c|c|c|c|c|}
\hline \multicolumn{2}{|c|}{ Ribs Dimensions } & Heat rate (W) & Qair $_{\text {a }}$ /min) & $\mathbf{Q}_{\text {water }}(\mathbf{L} / \mathbf{m i n})$ \\
\hline Pitch (mm) & Height $(\mathbf{m m})$ & & & \\
\hline \multirow{3}{*}{5} & 12 & 80 & 5.83 & 5 \\
\cline { 2 - 5 } & 15 & 100 & 8.33 & 7 \\
\cline { 2 - 5 } & 18 & 120 & 10.83 & 9 \\
\cline { 2 - 5 } & & & 16.66 & 12 \\
\hline
\end{tabular}


Table 2: The flow rate of air and fluid for Pitch $=5 \mathrm{~mm}$, and height $=18$ with $\mathrm{q}=80,100 \&$ 120Watt)

\begin{tabular}{|c|c|c|c|c|c|c|c|}
\hline \multicolumn{4}{|c|}{$\begin{array}{c}\mathrm{q}=80 \text { Watt, Pitch }=5 \mathrm{~mm} \text { and height } \\
=18 \mathrm{~mm}\end{array}$} & \multicolumn{2}{|c|}{$\begin{array}{c}\mathrm{q}=100 \text { Watt, } \text { Pitch }=5 \mathrm{~mm} \\
\text { and height }=18 \mathrm{~mm}\end{array}$} & \multicolumn{2}{|c|}{$\begin{array}{c}\mathrm{q}=120 \text { Watt, Pitch }=5 \mathrm{~mm} \\
\text { and height }=18 \mathrm{~mm}\end{array}$} \\
\hline $\begin{array}{l}\mathrm{Q}_{\text {water }} \\
\text { (L/Min) }\end{array}$ & $\begin{array}{c}\mathrm{Q}_{\text {air }} \\
\text { (L/Min) }\end{array}$ & Fluid temp. & $\begin{array}{l}\text { Ribs } \\
\text { temp. }\end{array}$ & Fluid temp. & Ribs temp. & $\begin{array}{l}\text { Fluid } \\
\text { temp. }\end{array}$ & Ribs temp. \\
\hline \multirow[t]{4}{*}{5} & 5.83 & 31.4 & $\overline{50.6}$ & 30 & 55.4 & 31.1 & 60.7 \\
\hline & 8.33 & 31.6 & 50.1 & 30.2 & 54.8 & 31.2 & 60.1 \\
\hline & 10.83 & 31.8 & 49.3 & 30.4 & 54.2 & 31.4 & 59.5 \\
\hline & 16.83 & 32.1 & 47.8 & 30.7 & 52.8 & 31.6 & 57.9 \\
\hline \multirow[t]{4}{*}{7} & 5.83 & 30.9 & 49 & 28.5 & 53.1 & 30.7 & 58.8 \\
\hline & 8.33 & 31.1 & 48.6 & 28.6 & 52.4 & 30.8 & 58.2 \\
\hline & 10.83 & 31.3 & 47.6 & 28.8 & 51.9 & 31 & 57.3 \\
\hline & 16.83 & 31.6 & 46.1 & 30.2 & 51.9 & 31.3 & 55.9 \\
\hline \multirow[t]{4}{*}{9} & 5.83 & 30.6 & 48 & 28.3 & 51.4 & 30.2 & 57 \\
\hline & 8.33 & 30.7 & 47.3 & 28.4 & 50.8 & 30.3 & 56.1 \\
\hline & 10.83 & 31 & 46.6 & 28.6 & 50.5 & 30.4 & 55.1 \\
\hline & 16.83 & 31.2 & 45.1 & 28.9 & 49.1 & 30.7 & 53.6 \\
\hline \multirow[t]{4}{*}{12} & 5.83 & 30 & 46.4 & 27.8 & 49.8 & 29.7 & 54.7 \\
\hline & 8.33 & 30.2 & 45.8 & 28 & 49.1 & 29.9 & 54 \\
\hline & 10.83 & 30.5 & 45.1 & 28.2 & 48.7 & 30.1 & 53.7 \\
\hline & 16.83 & 30.9 & 43.9 & 28.5 & 47.3 & 30.2 & 52 \\
\hline
\end{tabular}

Table 3: The flow rate of air and fluid for Pitch $=5 \mathrm{~mm}$, and height $=15$ with $\mathrm{q}=80,100 \&$ 120Watt)

\begin{tabular}{|c|c|c|c|c|c|c|c|}
\hline \multicolumn{4}{|c|}{$\begin{array}{c}\mathrm{q}=80 \text { Watt, Pitch }=5 \mathrm{~mm} \text { and height } \\
=15 \mathrm{~mm}\end{array}$} & \multicolumn{2}{|c|}{$\begin{array}{l}\mathrm{q}=100 \text { Watt, Pitch } \\
=5 \mathrm{~mm} \text { and height } \\
=15 \mathrm{~mm}\end{array}$} & \multicolumn{2}{|c|}{$\begin{array}{c}\mathrm{q}=120 \text { Watt, Pitch }=5 \mathrm{~mm} \\
\text { and height }=15 \mathrm{~mm}\end{array}$} \\
\hline $\begin{array}{l}\mathrm{Q}_{\text {water }} \\
\text { (L/Min) }\end{array}$ & $\begin{array}{c}\mathrm{Q}_{\text {air }} \\
\text { (L/Min) }\end{array}$ & $\begin{array}{l}\text { Fluid } \\
\text { temp. }\end{array}$ & $\begin{array}{l}\text { Ribs } \\
\text { temp. }\end{array}$ & $\begin{array}{l}\text { Fluid } \\
\text { temp. }\end{array}$ & $\begin{array}{l}\text { Ribs } \\
\text { temp. }\end{array}$ & $\begin{array}{l}\text { Fluid } \\
\text { temp. }\end{array}$ & Ribs temp. \\
\hline \multirow[t]{4}{*}{5} & 5.83 & 29.1 & 58.6 & 30.3 & 61.3 & 31.4 & 63.3 \\
\hline & 8.33 & 29.2 & 57.5 & 30.4 & 60.9 & 31.6 & 62.6 \\
\hline & 10.83 & 29.4 & 56.9 & 30.6 & 60.1 & 31.8 & 62 \\
\hline & 16.83 & 29.6 & 55.8 & 30.9 & 59 & 32.1 & 60.4 \\
\hline \multirow[t]{4}{*}{7} & 5.83 & 28.6 & 57.5 & 29.8 & 60.2 & 30.9 & 62.1 \\
\hline & 8.33 & 28.8 & 56.8 & 30 & 59.4 & 31.1 & 61.7 \\
\hline & 10.83 & 29 & 56.1 & 30.3 & 58.6 & 31.3 & 60.8 \\
\hline & 16.83 & 29.3 & 55.1 & 30.6 & 57.6 & 31.6 & 59.5 \\
\hline \multirow[t]{4}{*}{9} & 5.83 & 28.2 & 56.3 & 29.5 & 59.3 & 30.6 & 61.4 \\
\hline & 8.33 & 28.3 & 55.5 & 29.6 & 58.6 & 30.7 & 60.6 \\
\hline & 10.83 & 28.5 & 54.9 & 29.9 & 57.9 & 31 & 60.1 \\
\hline & 16.83 & 28.8 & 53.8 & 30.2 & 56.8 & 31.2 & 58.5 \\
\hline \multirow[t]{3}{*}{12} & 5.83 & 27.7 & 55.2 & 28.9 & 58 & 30 & 59.5 \\
\hline & 8.33 & 27.8 & 54.6 & 29.1 & 57.4 & 30.2 & 58.6 \\
\hline & 10.83 & 28.1 & 54 & 29.4 & 57 & 30.5 & 58 \\
\hline
\end{tabular}




\begin{tabular}{|c|c|c|c|c|c|c|c|}
\hline & 16.83 & 28.4 & 53 & 29.7 & 55.9 & 30.9 & 56.8 \\
\hline \multicolumn{8}{|c|}{$\begin{array}{l}\text { Table 4: The flow rate of air and fluid for Pitch }=5 \mathrm{~mm} \text {, and height }=12 \text { with } \mathrm{q}=80,100 \& \\
\qquad \text { 120Watt) }\end{array}$} \\
\hline \multicolumn{4}{|c|}{$\begin{array}{c}\mathrm{q}=80 \text { Watt, Pitch }=5 \mathrm{~mm} \text { and height } \\
=12 \mathrm{~mm}\end{array}$} & \multicolumn{2}{|c|}{$\begin{array}{c}\mathrm{q}=100 \text { Watt, Pitch } \\
=5 \mathrm{~mm} \text { and height } \\
=12 \mathrm{~mm}\end{array}$} & \multicolumn{2}{|c|}{$\begin{array}{l}\mathrm{q}=120 \mathrm{Watt}, \text { Pitch }=5 \mathrm{~mm} \\
\text { and height }=12 \mathrm{~mm}\end{array}$} \\
\hline $\begin{array}{l}\text { Qwater } \\
\text { (L/Min) }\end{array}$ & $\begin{array}{l}\text { Qair } \\
\text { (L/Min) }\end{array}$ & $\begin{array}{l}\text { Fluid } \\
\text { temp. }\end{array}$ & Ribs temp. & $\begin{array}{l}\text { Fluid } \\
\text { temp. }\end{array}$ & Ribs temp. & $\begin{array}{l}\text { Fluid } \\
\text { temp. }\end{array}$ & Ribs temp. \\
\hline \multirow[t]{4}{*}{5} & 5.83 & 29.1 & 58.6 & 30.3 & 61.3 & 31.4 & 63.3 \\
\hline & 8.33 & 29.2 & 57.5 & 30.4 & 60.9 & 31.6 & 62.6 \\
\hline & 10.83 & 29.4 & 56.9 & 30.6 & 60.1 & 31.8 & 62 \\
\hline & 16.83 & 29.6 & 55.8 & 30.9 & 59 & 32.1 & 60.4 \\
\hline \multirow[t]{4}{*}{7} & 5.83 & 28.6 & 57.5 & 29.8 & 60.2 & 30.9 & 62.1 \\
\hline & 8.33 & 28.8 & 56.8 & 30 & 59.4 & 31.1 & 61.7 \\
\hline & 10.83 & 29 & 56.1 & 30.3 & 58.6 & 31.3 & 60.8 \\
\hline & 16.83 & 29.3 & 55.1 & 30.6 & 57.6 & 31.6 & 59.5 \\
\hline \multirow[t]{4}{*}{9} & 5.83 & 28.2 & 56.3 & 29.5 & 59.3 & 30.6 & 61.4 \\
\hline & 8.33 & 28.3 & 55.5 & 29.6 & 58.6 & 30.7 & 60.6 \\
\hline & 10.83 & 28.5 & 54.9 & 29.9 & 57.9 & 31 & 60.1 \\
\hline & 16.83 & 28.8 & 53.8 & 30.2 & 56.8 & 31.2 & 58.5 \\
\hline \multirow[t]{4}{*}{12} & 5.83 & 27.7 & 55.2 & 28.9 & 58 & 30 & 59.5 \\
\hline & 8.33 & 27.8 & 54.6 & 29.1 & 57.4 & 30.2 & 58.6 \\
\hline & 10.83 & 28.1 & 54 & 29.4 & 57 & 30.5 & 58 \\
\hline & 16.83 & 28.4 & 53 & 29.7 & 55.9 & 30.9 & 56.8 \\
\hline
\end{tabular}

\section{REFERENCES}

Tian, J., Qi, C., Sun, Y., Yaseen, Z.M. and Pham, B.T., 2020. Permeability prediction of porous media using a combination of computational fluid dynamics and hybrid machine learning methods. Engineering with Computers, pp.1-17.

Salih, S.Q., Aldlemy, M.S., Rasani, M.R., Ariffin, A.K., Ya, T.M.Y.S.T., Al-Ansari, N., Yaseen, Z.M. and Chau, K.W., 2019. Thin and sharp edges bodies-fluid interaction simulation using cut-cell immersed boundary method. Engineering Applications of Computational Fluid Mechanics, 13(1), pp.860-877.

Yaseen, Z.M., Keshtegar, B., Hwang, H.J. and Nehdi, M.L., 2019. Predicting reinforcing bar development length using polynomial chaos expansions. Engineering Structures, 195, pp.524535.

Al-Naely, H., Al-Khafaji, Z. and Khassaf, S., 2018. Effect of Opening Holes on the Hydraulic Performance for Crump Weir. International Journal of Engineering, 31(12), pp.2022-2027.

Al-Zubaidy, B., Radhi, N.S. and Al-Khafaji, Z.S., 2019. Study the effect of thermal impact on the modelling of (titanium-titania) functionally graded materials by using finite element analysis. 
Abdulrazzaq, T., Togun, H., AAriffin, M.K., Kazi, S.N., Adam, N.M. and Masuri, S., 2013. Numerical simulation on heat transfer enhancement in channel by triangular ribs. Int. J. of Mech. Aerospace Industrial Mechanotronic and Manufacturing Engineering, 7(8).

Togun, H., 2016. Effect of laminar separation flow and nanofluids on heat transfer augmentation with passive techniques: A review. International Communications in Heat and Mass Transfer, 77, pp.9-14.

Guptaa, P., Sharmab, A.K. and Kumarc, R., 2018. Simulation of Internally Fitted Baffles in STHEx for Different Reynolds Number. International Journal of Applied Engineering Research, 13(6), pp.278-285.

Al-Jibory, M.W., 2018. Heat Transfer Enhancement for Rectangular Channels by Using Triangular-Shaped Ribs at High Reynold Numbers. journal of kerbala university, 16(1), pp.114-124.

Golam, A.S., 2018. Numerical and Experimental Investigation of Heat Transfer Features in a Square Duct with Internal Ribs. Wasit Journal of Engineering Sciences, 6(3), pp.51-68.

Promvonge, P., Pethkool, S., Pimsarn, M. and Thianpong, C., 2012. Heat transfer augmentation in a helical-ribbed tube with double twisted tape inserts. International Communications in Heat and Mass Transfer, 39(7), pp.953-959.

Zhang, C., Wang, D., Ren, K., Han, Y., Zhu, Y., Peng, X., Deng, J. and Zhang, X., 2016. A comparative review of self-rotating and stationary twisted tape inserts in heat exchanger. Renewable and Sustainable Energy Reviews, 53, pp.433-449.

Bhuiya, M.M.K., Azad, A.K., Chowdhury, M.S.U. and Saha, M., 2016. Heat transfer augmentation in a circular tube with perforated double counter twisted tape inserts. International Communications in Heat and Mass Transfer, 74, pp.18-26.

Piriyarungrod, N., Eiamsa-Ard, S., Thianpong, C., Pimsarn, M. and Nanan, K., 2015. Heat transfer enhancement by tapered twisted tape inserts. Chemical Engineering and Processing: Process Intensification, 96, pp.62-71.

M. R. Ansari and B. Arzandi, "Two-phase gas--liquid flow regimes for smooth and ribbed rectangular ducts,” Int. J. Multiph. Flow, vol. 38, no. 1, pp. 118-125, 2012.

Turaihi, R.S.A., Al-Jibory, M.W. and Al-Jibory, H.N., 2018. Heat Transfer Enhancement in Vertical Channel for Two Phase Flow by using Compound Turbulater. Journal of University of Babylon, 26(1), pp.60-71.

Van Eckeveld, A.C., Gotfredsen, E., Westerweel, J. and Poelma, C., 2018. Annular two-phase flow in vertical smooth and corrugated pipes. International Journal of Multiphase Flow, 109, pp.150-163.

S. Karthikeyan, N. Elumalai, and K. Narasingamurthi, "Experimental study of developing turbulent flow and heat transfer in ribbed convergent/divergent rectangular ducts," Therm. Sci., vol. 19, no. 6, pp. 2219-2231, 2015. 
Sivakumar, K., Kulasekharan, N. and Natarajan, E., 2018. Computational Investigations in Rectangular Convergent and Divergent Ribbed Channels. International Journal of Turbo \& Jet-Engines, 35(2), pp.193-201.

Kashif, A.L.I., Ahmad, S., Ashraf, M. and Kamal, M.A., 2018. Numerical simulation of flow reversal at high rayleigh number in a vertical square duct. thermal science, 22(6b), pp.28972907.

Sorour, M.M., Fayed, M. and El-Din, N.A., 2019. Heat Transfer Enhancement in a Radial Turbulent Sink Flow Cooling System. Journal of Thermal Science and Engineering Applications, 11(3), p.031003.

R. Kong and S. Kim, “Characterization of horizontal air--water two-phase flow,” Nucl. Eng. Des, vol. 312, pp. 266-276, 2017.

Kong, R., Rau, A., Lu, C., Gamber, J., Kim, S., Bajorek, S., Tien, K. and Hoxie, C., 2018. Experimental study of interfacial structure of horizontal air-water two-phase flow in a 101.6 mm ID pipe. Experimental Thermal and Fluid Science, 93, pp.57-72.

Kong, R., Kim, S., Bajorek, S., Tien, K. and Hoxie, C., 2016, January. Evaluation of interfacial area transport models for horizontal bubbly flow. In Proceedings of 2016 International Topical Meeting on Advances in Thermal Hydraulics (pp. 12-16).

P. Hanafizadeh, A. Shahani, A. Ghanavati, and M. A. Akhavan-Behabadi, "Experimental investigation of air-water-oil three-phase flow patterns in inclined pipes," Exp. Therm. Fluid Sci., vol. 84, pp. 286-298, 2017. 